\title{
Efficiency of immunologic researches in stabilization of productivity of sunflower
}

\author{
V. Kyrychenko, \\ Academician of NAAS, Doctor of Agricultural Sciences \\ V. Petrenkova, \\ Corresponding Member. NAAS, Doctor of Agricultural Sciences \\ V. Kolomatska, \\ Doctor of Agricultural Sciences \\ I. Borovska, \\ Candidate of Agricultural Sciences \\ N. Yegorova, \\ Candidate of Agricultural Sciences \\ Plant Production Institute named after VYa Yuryev NAAS
}

The purpose. To determine genotypes of sunflower with high level of resistance to agents of false mildew, phomopsis and gray mould. Methods. Field, laboratory, statistical. Results. 21 high-yielding hybrids of sunflower with high disease resistance are created by the method of using in selection program genotypes with chosen attributes. Conclusions. The variance in productivity of hybrid-standard Dariy and newly created hybrids Oreiol and Zlatson makes 0,34 and $0,38 \mathrm{t} /$ hectare that increases index of profit for 1 ton for 52,3 and $483,9 \mathrm{hrn}$, and level of profitableness - for 2 and $20 \%$ accordingly.

Key words: sunflower, selection, hybrid, resistance, sicknesses, immunologic researches, economic efficiency.

Sunflower is the main oil crop in Ukraine among, occupies $70.0 \%$ of the area under oil crops and accounts for $85.0 \%$ of the gross yield. The high demand for oil and meal both in Ukraine and in other countries encourages producers to grow sunflower as a lucrative crop, which is one of the major sources of their income [1, 2]. Over the past 15 years, the production of sunflower seeds in Ukraine has increased to $11,181,000$ tons or by three times, which was due to the increase in the acreage to $5,105,000$ ha (or by $75.0 \%$ ). The yield capacity of this crop has also grown to $2.16 \mathrm{t} / \mathrm{ha}$ (as of 09.07 .2016 ) [3, 4]. In 2015, the average profitability of the plant production in the agribusiness of Ukraine increased to $50.0 \%$ as compared to 2014 [5]. Calculations of the NSC "Institute of Agrarian Economy" NAAS of Ukraine show that in 2017 a rise in costs for production and sale of all crop products from 10.0 to $30.0 \%$ is expected. At year-end 2016 , the expected first costs for sunflower will be $508.0 \mathrm{UAH} / \mathrm{dt}$ or higher by $20.8 \%$ than those in the previous year [5].

High sunflower yields, especially in years favoring intensive dissemination and development of major diseases, are possible provided that biotic factor-resistant accessions are available in breeding [6].

Among institutions of the National Academy of Agrarian Sciences of Ukraine, three research institutions successfully work at sunflower breeding and seed production. They are the Plant Production Institute (PPI) nd. a VYa Yuryev NAAS (Kharkiv), which is the main agency of research portfolio 15 of NAAS "Oil Crops", Plant Breeding and Genetics Institute - National Center for Cultivar and Seed Investigation (Odessa), Institute of Oil Crops NAAS (Zaporizhzhia). The portfolio envisages development of theoretical principles and justification of efficient lines of creation of radically new sunflower starting material, intensification of fundemental research and verification of results in breeding practice by developing improved hybrids, which would be resistant to biological and abiotic factors, with enhanced performance and variable biochemical composition of seeds [7]. 
Goal - to identify genotypes with high resistance to downy mildew, Phomopsis blight and bud rot and to use them in a breeding program to create high-yielding sunflower hybrids.

Results. Sunflower breeding for resistance to major pathogens is scientifically and methodically based on their species specificity and, accordingly, on genetic nature of resistance. The experience of leading breeders of the world [8] and our long-term observations demonstrate that immunological assessments of breeding material should be directed by nutrition type of pathogens in culture. Thus, in sunflower breeding for resistance to downy mildew there is a dynamic sequence of phytopathological evaluation of breeding material (lines and hybrids) in the field in years with strong prevalence and mass destruction of plants (epiphytotics) along with continuous annual evaluation under the laboratory conditions. Using a rapid assessment method of resistance of sunflower accessions at the seedling phase, biotypes - carriers of dominant genes of resistance to a currently virulent pathogenic race are selected among tens of thousands of genotypes. This approach is economically viable due to low first costs of the rapid assessment method. Only genotypes with resistance to downy mildew confirmed by three-year laboratory evaluation are screened by molecular genetic methods of analysis.

Use of provocative background with natural variability of disease development caused by agrometeorological factors is a peculiarity of determination of sunflower resistance to agents of bud rot and Phomopsis blight. This approach allows us to identify resistant to these pathogens lines and hybrids, resistance of which is inextricably intertwined with resistance to abiotic environmental factors.

Results of immunological studies served as foundation for each breeding project in 2007-2016, since they provided an advantage for manifestation of the genetic potential of 21 sunflower hybrids, of which 10 hybrids are listed in the State Register of Plant Varieties Suitable for Dissemination Ukraine, basing on results of the state variety trials ('Kursor', ,Truvor,, 'Sonahro', 'Sibson', 'Oreol', 'Yurievskyy', 'Batiania', 'Zlatson', 'Expert', and 'Rytsar'), and 11 hybrids ('Prestizh', 'Hoduvalnyk', 'Azhur', 'Iziumskyy', 'Dekan', 'Sirius', 'Metalist', 'Staier', 'Trevel', 'Ravelin', and 'Fenomen') are being tested in the state variety trials. These hybrids are characterized by a number of valuable agronomic traits. First, their resistance to downy mildew is very high (9 points); resistance to Phomopsis blight and bud rot is considered high (7 points). Secondly, according to the growing season length, hybrids are sort-season (97-99 days - 'Kursor', 'Sonahro', 'Sibson', 'Batiania') and early-ripening (101-104 days - 'Truvor', 'Oreol', 'Yurievskyy', 'Zlatson', 'Azhur', 'Iziumskyy', 'Sirius'). In terms of fatty acid composition of oil, hybrids are linoleic and oleic (85.19\% 'Oreol') or palmitic (15.93\% - 'Truvor'). They are oil-producing and confectionary ('Sponsor'). 'Trevel', 'Ravelin', 'Fenomen', and 'Hoduvalnyk', which are noticeable for tolerance resistance to herbicides, were designed for intensive cultivation technologies.

Advantages of the sunflower hybrids created and implemented in agro-industry, which provided an increase in the yield by $0.02-0.38 \mathrm{t} / \mathrm{ha}$ as compared to the standards of corresponding ripeness groups ('Kyy' [short-season] and 'Dariy' [early-ripening]) and an annual gain of 1,000 - 1,900 UAH/ha, are economically justified (Table 1).

1. Costs of the Gain from Cultivation of the Sunflower Hybrids listed in the Register of Plant Varieties of Ukraine (competitive variety trial at the Plant Production Institute named after VYa Yuryev NAAS), 2016

\begin{tabular}{|c|c|c|c|}
\hline \multirow[b]{2}{*}{ Hybrid } & \multicolumn{2}{|c|}{ Yield, t/ha } & \multirow[b]{2}{*}{ Gain costs, UAH/ha } \\
\hline & Mean & $\begin{array}{l} \pm \text { related to the } \\
\text { standard }\end{array}$ & \\
\hline \multicolumn{4}{|c|}{ Short-season } \\
\hline 'Kursor' & 3.21 & 0.02 & 1,000 \\
\hline 'Kyy', st & 3.19 & - & - \\
\hline \multicolumn{4}{|c|}{ Early-ripening } \\
\hline ‘Oreol’ & 3.90 & 0.22 & 11,000 \\
\hline 'Zlatson' & 3.94 & 0.38 & 19,000 \\
\hline
\end{tabular}




\begin{tabular}{|l|l|l|l|}
\hline 'Expert' & 3.06 & 0.09 & 4,500 \\
\hline 'Dariy', st & 3.56 & - & - \\
\hline
\end{tabular}

'Kursor', 'Oreol', 'Zlatson', and 'Expert' were grown on farms of the Kharkiv, Dnipro, Kyiv, Poltava, Odessa, Sumy, Kherson, Kyrovohrad, Luhansk, Donetsk, Zaporizhzhia, and Mykolaiv regions on the area of about 250,000 ha in 2011-2015.

Every year seed production farms of different ownership forms lay out hybridization plots to obtain seeds of new high-yielding hybrids with high resistance to common pathogens of sunflower (Table 2).

For example, in 2011-2016 on farms of the Kharkiv region with hybridization plots, which were 3,092 hectares in the total area, seeds of F hybrids 'Kursor', 'Oreol', 'Zlatson', and 'Expert' were grown for commercial sunflower crops with the area of $67,000-2,313,000$ hectares annually.

2. Production of PPI's hybrid seeds in Ukraine, 2007-2016

\begin{tabular}{|l|l|l|l|l|l|l|l|}
\hline \multirow{2}{*}{ Hybrid } & \multicolumn{6}{l}{ Hybridization plot area, ha } \\
\cline { 2 - 9 } & $\mathbf{2 0 1 1}$ & $\mathbf{2 0 1 2}$ & $\mathbf{2 0 1 3}$ & $\mathbf{2 0 1 4}$ & $\mathbf{2 0 1 5}$ & $\mathbf{2 0 1 6}$ & Total \\
\hline 'Kursor' & 200 & 200 & - & 5 & - & - & 405 \\
\hline 'Oreol' & - & - & - & 86 & 155 & 66 & 307 \\
\hline 'Zlatson' & - & - & - & 415 & 937 & 961 & 2,313 \\
\hline 'Expert' & - & - & - & 67 & - & - & 67 \\
\hline Total & 200 & 200 & - & 506 & 1,159 & 1,027 & 3,092 \\
\hline
\end{tabular}

Comprehensive assessment of innovative products, when sunflower hybrid seeds $\left(F_{1}\right)$ are grown for commercial crops, covers both results of immunological studies and economic parameters, taking into account material, labor and financial resources and providing gain in the yield, cost savings and rise in profitability of each ton of sunflower seeds. This helps unlock benefits of new hybrids in the market and enables fulfilling their genetic potential. Consequently, we determined the level of expenditures and profit index for growing $F$ seeds of sunflower hybrids 'Dariy' (St), 'Oreol' and 'Zlatson' for commercial crops (Table 3).

According to flow process charts for sunflower cultivation, we assumed the use of modern equipment and a judicious ratio of resources to obtain seed yields of the aforementioned hybrids of 3.56, 3.90 and 3.94 t/ha, respectively [9-11]. The findings point to the need for optimization of total costs upon growing $F$ sunflower hybrid seeds, importance of evaluation of resistance of genotypes to pathogens, and analysis of immunological studies, because this is a foundation for each hybrid, providing increased yields, reduced costs and, as a consequence, increased profitability of each ton of sunflower seeds.

3. Economic efficiency of growing $F_{1}$ sunflower hybrids for commercial crops (level of use of the traditional domestic appliances), 2016

\begin{tabular}{|c|c|c|c|}
\hline \multirow{2}{*}{ Parameters } & \multicolumn{3}{|c|}{$\begin{array}{l}\text { Expenditures per ton of commercia } \\
\text { product, UAH }\end{array}$} \\
\hline & 'Dariy' (St) & ‘Oreol’ & 'Zlatson' \\
\hline Yield, t/ha & 3.56 & 3.90 & 3.94 \\
\hline Difference in the yield, \pm t/ha & - & +0.34 & +0.38 \\
\hline \multicolumn{4}{|l|}{ Input cost- total: } \\
\hline perha & $18,792.88$ & $20,383.7$ & $18,892.3$ \\
\hline perton & 5278.9 & 5226.6 & 4795.0 \\
\hline Netback price, UAH/t & $10,500.0$ & & \\
\hline Profit per ton, UAH & $5,221.1$ & $5,273.4$ & $5,705.0$ \\
\hline Break-even level, \% & 99.0 & 101.0 & 119.0 \\
\hline $\begin{array}{l}\text { Difference in the profit index per ton between hybrid and } \\
\text { standard, UAH }\end{array}$ & - & +52.3 & +483.9 \\
\hline
\end{tabular}

Our calculations reflect benefits of new hybrids over standard of a corresponding ripeness group, since the "standard 'Dariy' - hybrid" difference in the yield for 'Oreol' and 'Zlatson' is 0.34 and $0.38 \mathrm{t} / \mathrm{ha}$, 
increasing the profit index per ton by $52.3483 .9 \mathrm{UAH}$, respectively, and the break-even level by $2.0 \%$ and $20.0 \%$, respectively.

\section{Conclusions}

The comprehensive system of immunological assessments and phytopathological support of sunflower breeding projects at all stages of the breeding process and during the final evaluation in the competitive trials in the Laboratory of Sunflower Breeding and Genetics of the Plant Production Institute nd. a VYa Yuryev NAAS proved the effectiveness of involvement of genotypes that are reliably resistant to downy mildew, Phomopsis blight and bud rot in breeding programs, which contributed to development of 21 highyielding sunflower hybrids with high resistance (9 points) to downy mildew and high resistance (7 points) to Phomopsis blight and bud rot. These hybrids are listed in the State Register of Plant Varieties Suitable for Dissemination in Ukraine ('Kursor' [short-season], 'Oreol, 'Zlatson', 'Expert' [early ripening]). We determined that the yields of hybrids exceeded those of the standards of short-season and early-ripening groups ('Kyy' and 'Dariy') by 0.02 ('Kursor') to 0.38 t/ha ('Zlatson'), which provides the annual gain from growing hybrids of 1,000-19,000 UAH/ha. 'Kursor', 'Oreol', 'Zlatson', 'Expert' listed in the State Register of Plant Varieties Suitable for Dissemination in Ukraine were introduced in the agribusiness of Ukraine on the area of about 250,000 ha in 2007-2016. Seed production farms of the Kharkiv region laid out hybridization plots to produce seeds of these hybrids, providing cultivation of commercial sunflower on the area of 67,000 $2,313,000$ hectares annually. The difference in the yield between standard 'Dariy' and hybrids 'Oreol' and 'Zlatson' is 0.34 and $0.38 \mathrm{t} / \mathrm{ha}$, respectively, which increases the profit index per ton by 52.3 and $483.9 \mathrm{UAH}$, respectively, and the break-even level by $2.0 \%$ and $200 \%$, respectively.

\section{References}

1. Melikh O.O. The current state of the market trends of sunflower oil in Ukraine / OO Melikh, NV Pasmenko // Ekonomika kharchovoyi promyslovosti. - 2015. - Vol. 7. — Issue. 3. - P. 15-20.

2. Hladni N. Present status and future prospects of global confectionery sunflower production / N. Hladni // Proceedings of 19-th International sunflower conference 29 may - 3 june 2016, Edirne, Turkey. - 2016. P. 47-60.

3. Plant production: acreage of major crops, sunflower seed production and yield [electronic source]. Access: http://www.ukrstat.gov.ua/.

4. On sunflower cultivation in Ukraine [electronic source]. - Access: http://minagro.gov.ua/node/14332.

5. Cherednychenko O.O. Economic efficiency of sunflower production and processing and ways of its improvement in Artsyz district of the Odessa region / OO Cherednychenko, TV Topalova // Naukovyy Visnyk Natsionalnoho Universytetu Bioresursiv i Pryrodokorystuvannia Ukrayiny. Series: Ekonomika, Ahrarnyy Menedzhment, Biznes. — 2013. — Issue. 181 (2). - P. 327-334.

6. Masirevic S. sunflower diseases research progress and management / S. Masirevic // Proceedings of 19-th International sunflower conference 29 may - 3 june 2016, Edirne, Turkey. - 2016. - P. 61-70.

7. Kyrychenko V.V. Results and prospects of research on sunflower breeding in Ukraine / VV Kyrychenko, KM Makliak, OV Kryvosheieva [et al] // Selektsiya i Nasinnytstvo. — 2011. — Issue 99. — P. 3-10.

8. Sunflower genetics and breeding / D. Shkorych, D.J. Seiler, Zhao Liu [et al.] International monograph / Serbian Academy of Sciences and Arts, Association "Selection and seed sunflower", Kharkiv. - Kh.: NTMT, 2015. $-540 \mathrm{p}$.

9. Flow charts and costs for growing crops with different resource support / ed. by DI Mazorenko, HYe Mazniev. - Kharkiv: KhNTUSH im. Vasylenka, 2006. - 725 p.

10. Innovative resource-saving technologies: efficiency upon various financial status of farming enterprises: [monograph] / ed. by Prof. HYe Mazniev. — Kharkiv: Maidan, 2014. — 592 p.

11. Kononenko V.A. Expenditure account and efficiency of sunflower production at farming enterprises / VA Kononenko, OM Barbiniahra // Ekonomichni Nauky // Young Scientist. — 2016. — No 7 (34). — P. 59—62. 